\title{
Hubungan antara Efikasi Diri dan Pengetahuan Lingkungan dengan Perilaku Bertanggung Jawab terhadap Lingkungan
}

\section{Relationship between Self-Efficacy and Environment Knowledge with Responsibility Environment Behavior}

\author{
Asrar Habibie ${ }^{*}$ \\ ${ }^{1}$ Badan Pelatihan dan Pendidikan, Provinsi Gorontalo, Indonesia \\ *Email Korespondensi: asrar_habibie@yahoo.com \\ doi: http://dx.doi.org/10.29405/j.bes/4121-264805
}

Received: 25 Maret 2020 | Accepted:06 April 2020 | Published: 30 Juni 2020

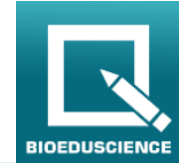

Abstrak

Background: Kepedulian dan rasa tanggung jawab manusia terhadap kelestarian lingkungan telah menarik minat peneliti dalam studi kesadaran lingkungan. Faktor-faktor yang berkaitan dengan kepedulian lingkungan juga berkontribusi dalam studi ini. Metode: Pendektan survei dengan teknik korelasional yang menggambarkan hubungan antar variabel diadopsi dalam penelitian ini. Survei ini mencakup 100 responden yang diperoleh dari $20 \%$ populasi terjangkau. Sampel diuji dengan analisis regresi dan korelasi. Hasil: Penelitian ini mengkonfirmasi bahwa adanya hubungan antara pengetahuan lingkungan dan efikasi diri dengan perilaku bertanggung jawab terhadap lingkungan. Kesimpulan: Perilaku bertanggung jawab terhadap lingkungan sangat bergantung pada pengetahuan lingkungan dan efikasi diri baik parsial maupun simultan merupakan kesimpulan dari studi ini.

Kata kunci: Pengetahuan lingkungan; Efikasi diri; Tanggung Jawab

\section{Abstract}

Background: The environment has attracted researchers' interest in environmental awareness studies. Factors related to environmental concern also contributed to this study. Methods: Factors related to environmental concern also contributed to this study. A survey approach using correlational techniques that illustrates the relationship between variables was adopted in this study. This survey includes 100 respondents who obtained from $20 \%$ of the affordable population. Samples were tested by regression and correlation analysis. Results: This research confirms that there is a relationship between environmental knowledge and self-efficacy with environmentally responsible behavior. Conclusions: Responsible behavior towards the environment is very dependent on environmental knowledge and self-efficacy both partially and simultaneously is the conclusion of this study.

Keywords: Self Efficacy, Environmental Knowledge, Responsibility

Cara citasi: Habibie, A. 2020. Hubungan Antara Efikasi Diri dan Pengetahuan Tentang Lingkungan dengan Perilaku Bertanggung Jawab terhadap Lingkungan. BIOEDUSCIENCE: Jurnal Pendidikan Biologi dan Sains. 04(01): 21-26. Doi: http://dx.doi.org/10.29405/j.bes/4121-264805

(C) 2020 Oleh Bioeduscience: Jurnal Pendidikan Biologi dan Sains, Uhamka, Jakarta. Artikel ini bersifat open access yang didistribusikan di bawah syarat dan ketentuan Creative Commons Attribution (CC-BY) license. (http://creativecommons.org/licenses/by/4.0/).

\section{PENDAHULUAN}

Tumbuhnya kesadaran manusia terhadap masalah lingkungan adalah hal vital yang dihadapi umat manusia saat ini (Sadik \& Sadik, 2014).
Hal tersebut menjadi menarik karena manusia bukan satu-satunya yang menghuni bumi (Schutte \& Bhullar, 2017). Makhluk hidup lain seperti tumbuhan, hewan, dan mikroba bukanlah 
penghuni bumi yang netral dan pasif, melainkan terikat erat pada manusia (Sujarwanta, 2013). Artinya aktivitas manusia memiliki konsekuensi terhadap perubahan lingkungan hidup (Osman, Jusoh, Amlus, \& Khotob, 2014).

Perilaku peduli lingkungan merupakan ekspansi dari pengetahuan manusia terhadap ekosistem disekitarnya (Osman et al., 2014). Konservasi sumber daya alam yang berhubungan dengan ekosistem dihadapkan pada kepunahan spesies yang mengancam kelangsungan hidup manusia (Saribas, Teksoz, \& Ertepinar, 2014). Permasalahan lingkungan hidup berkaitan dengan pengetahuan, perilaku, dan sikap subjektif manusia (Slavoljub, Zivkovic, Sladjana, Dragica, \& Zorica, 2015). Karenanya kelestarian lingkungan dapat diperoleh melalui pengetahuan, perilaku sosial dan perubahan sikap individu dan kelompok (Fischer, 2012; Schutte \& Bhullar, 2017).

Rasa tanggung jawab mengenai masalah lingkungan berkaitan dengan norma pribadi yang didefinisikan sebagai perilaku seseorang dalam berbagai situasi (Slavoljub et al., 2015). Norma ini terdiri dari sikap tanggung jawab terhadap orang lain dan / atau alam (Abrahamse \& Steg, 2009). Mengurangai konsekuensi negatif yang ditimbulkan terhadap lingkungan merupakan bentuk peduli lingkungan. Perilaku peduli lingkungan pada manusia dapat dimodifikasi melalui self-efficacy (efikasi diri) (Bandura, 2002; Tabernero \& Hernández, 2011). Efikasi diri dapat dijadikan langkah awal untuk mengetahui seberapa jauh kemampuan individu terhadap sesuatu (Puspitaningtyas, 2017).

Sikap peduli lingkungan masyarakat Kota Gorontalo menarik minat peneliti untuk melakukan studi lanjut peduli lingkungan. Fakta bahwa Kota Gorontalo menerima penghargaan piala Adipura dua tahun berturut-turut sebagai kategori kota sedang terbersih dengan Visi SMART (Sejahtera, Maju, Aktif, Religius Dan Terdidik) telah mengantarkan kota ini mendapatkan penghargaan adipura (Gorontalo
Pemprov, 2016). Penghargaan yang diperoleh tidak terlepas dari masalah lingkungan. Fakta keberdaan tumpukan sampah di sudut-sudut kota yang menimbulkan penyumbatan pada selokanselokan air dan mengakibatkan banjir (Riawan, 2016).

Pencemaran laut juga menjadi masalah di daerah pesisir pantai dimulai dari membuang sampah ke laut dan masalah lain yang menyebabkan kerugian bagi masyarakat itu sendiri (Kadim \& Pasisingi, 2017). Permasalahan yang ada membuktikan bahwa visi yang bagus, belum sepenuhnya dipahami oleh masyarakat Kota Gorontalo baik di lingkungan keluarga, di lingkungan pendidikan, maupun di lingkungan kerja.

Uraian permasalahan yang terjadi di Kota Gorontalo, menarik peneliti untuk mengungkap perilaku bertanggung jawab terhadap lingkungan di Kota Gorontalo. Perilaku tanggung jawab terhadap lingkungan masyarakat Kota Gorontalo dapat diketahui dan dikembangkan melalui aspek pengetahuan tentang lingkungan dan efikasi diri.

Efikasi diri mengacu pada kepercayaan diri yang dimiliki individu pada kemampuan mereka, bahwa mereka dapat berhasil melakukan tugas tertentu (Mishra \& Shanwal, 2014). Artinya pada studi ini, efikasi diri dapat mengubah perilaku individu sehingga berhasil menciptakan kelestarian lingkungan disekitarnya. Efikasi diri terhadap lingkungan berorientasi pada perubahan perilaku lingkungan individu seperti daur ulang, konservasi sumber daya atau penghijauan (Huang, 2016). Tercapainya efikasi diri terhadap lingkungan tidak terlepas dari pengelolaan dan perlindungan lingkungan hidup yang terstruktur dan terpadu, dilakukan untuk melestarikan fungsi lingkungan hidup dan mencegah terjadinya pencemaran dan atau kerusakan lingkungan hidup yang meliputi perencanaan, pemanfaatan, pengendalian, pemeliharaan, pengawasan, dan penegakan hukum (UU RI No. RI 32 Tahun 2010).

Penelitian efikasi diri yang dilakukan oleh (Osman et al., 2014) menjelaskan bahwa 
pengetahuan lingkungan memiliki dampak signifikan terhadap perilaku sikap peduli lingkungan. Schutte \& Bhullar, (2017) dalam penelitiannya juga menjabarkan bahwa pengetahuan lingkungan berimplikasi pada perubahan sikap individu terkait kelestarian lingkungan. Faktanya kesadaran manusia akan dirinya sebagai bagian dari ekosistem masih terbilang rendah. Peningkatan kesadaran dan kepedulian lingkungan dapat diwujudkan melalui studi efikasi diri terhadap lingkungan agar keselarasan antara manusia dengan lingkungan dapat terwujud (Simanjuntak, 2016).

Kesadaran lingkungan dan faktor-faktor pengembangan untuk tanggung jawab lingkungan di antara individu telah menjadi fokus dalam studi ini. Pemahaman mengenai perilaku individu yang berkaitan dengan kelestarian lingkungan dimaksudkan untuk mengidentifikasi efikasi diri setiap individu yang berkontribusi dalam kasus ini. Selanjutnya akan dinarasikan hubungan antara variabel dalam kasus ini yang berguna sebagai informasi dalam pengembangan kasus serupa.

\section{MATERI DAN METODE}

Metode survei dengan teknik korelasional telah digunakan dalam penelitian ini. Metode ini dapat menjelaskan fenomenafenomena penelitian, yakni hubungan antar variabel penelitian. Secara skematik konstelasi masalah penelitian digambarkan sebagai berikut:

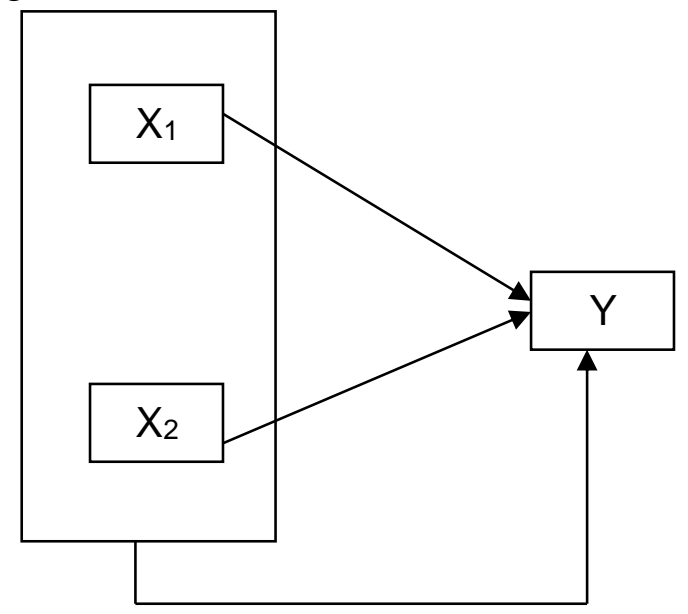

Gambar 1. Konstelasi Masalah

$\mathrm{X}_{1} \quad$ : Efikasi diri
$\mathrm{X}_{2} \quad$ : Pengetauan Lingkungan

Y : Perilaku Bertanggung Jawab

terhadap Lingkungan

Lingkup Penelitian

Penelitian deskriptif disarankan menggunakan sampel antara 10\% - 20\% dari populasi terjangkau (Ary, Jacobs, Razavieh, \& Sorensen, 2009). Sampel kasus ini sebanyak 100 masyarakat Kota Gorontalo yang diambil secara acak (20\% populasi terjangkau).

\section{Pengumpulan Data dan Analisis Data}

Data diperoleh menggunakan kuesioner yang berisi pernyataan. Nilai akhir kuesioner digunakan untuk mengetahui korelasi antar variabel. Uji hipotesis dilakukan untuk menguji korelasi antara variabel-variabel juga untuk mengetahui seberapa besar korelasi antara variabel-variabel bebas dengan variabel terikat, melalui analisis regresi dan korelasi.

\section{HASIL}

Hubungan Efikasi Diri $\left(X_{1}\right)$ dengan Perilaku Bertanggung Jawab terhadap Lingkungan $(Y)$.

Uji keberartian persamaan regresi, harga $F_{\text {hitung }}=102,14>F_{\text {tabel }}=6,91$. Hasil tersebut menunjukkan tolak Ho pada $\alpha=0,05$. Dengan demikian persamaan $\hat{Y}=0,06+0,79 X_{1}$ sangat signifikan. Untuk uji linearitas diperoleh harga $\mathrm{F}_{\text {hitung }}$ adalah $1,32<\mathrm{F}_{\text {tabel }}=1,60$. Hasil tersebut menunjukkan terima Ho pada $\alpha=0,05$. Dengan demikian persamaan regresi $\hat{Y}=0,06+0,79 \mathrm{X}_{1}$ bersifat linier.

Berdasarkan interpretasi hasil uji diatas dapat disimpulkan bahwa pengujian hipotesis kedua yang menyatakan "terdapat hubungan posistif antara efikasi diri dengan perilaku bertanggung jawab terhadap lingkungan siswa kelas VIII SMP di Kota Ternate teruji”.

Hubungan Pengetahuan Lingkungan $\left(X_{2}\right)$ dengan Perilaku Bertanggung Jawab terhadap Lingkungan $(Y)$.

Uji keberartian persamaan regresi, harga Fhitung $=81,33>$ Ftabel 6,91. Hasil tersebut 
menunjukkan tolak Ho pada $\alpha=0,05$. Dengan demikian persamaan $\hat{\mathrm{Y}}=54,64+1,61 \mathrm{X} 2$ sangat signifikan. Untuk uji linearitas diperoleh harga Fhitung adalah 1,56 $<$ Ftabel $=1,71$. Hasil tersebut menunjukkan terima Ho pada $\alpha=0,05$. Dengan demikian persamaan regresi $\hat{Y}=54,64+1,61 \mathrm{X} 2$ bersifat linier.

Berdasarkan interpretasi hasil uji diatas dapat disimpulkan bahwa pengujian hipotesis pertama yang menyatakan terdapat hubungan posistif antara pengetahuan tentang lingkungan dengan perilaku bertanggung jawab terhadap lingkungan siswa kelas VIII SMP di kota Ternate teruji.

Hubungan Efikasi Diri $\left(X_{1}\right), \quad$ Pengetahuan Lingkungan $\left(\mathrm{X}_{2}\right)$ dengan Perilaku Bertanggung Jawab terhadap Lingkungan $(Y)$.

Hasil uji signifikannya diperoleh harga $F_{\text {hitung }}=80,84>F_{\text {tabel }}=4,82$. Hasil tersebut menunjukkan tolak Ho pada $\alpha=0,05$ yang berarti persamaan regresi $\hat{Y}=9,83+0,97 \mathrm{X}_{1}+0,55 \mathrm{X}_{2}$ adalah signifikan. Berdasarkan hasil tersebut, terdapat hubungan positif antara pengetahuan tentang lingkungan $\left(\mathrm{X}_{1}\right)$, dan efikasi diri $\left(\mathrm{X}_{2}\right)$ bersama-sama dengan perilaku bertanggungjawab terhadap lingkungan (Y).

Koefisien determinasi dari korelasi ganda $\left(\mathrm{R}_{\mathrm{y} .12}^{2}\right)$ sebesar 0,6244 dapat diinterpretasikan bahwa $62 \%$ proporsi varians perilaku bertanggungjawab terhadap lingkungan (Y) dapat dijelaskan secara bersama-sama oleh pengetahuan tentang lingkungan $\left(\mathrm{X}_{1}\right)$ dan efikasi diri $\left(\mathrm{X}_{2}\right)$.

\section{PEMBAHASAN}

Hipotesis kami dalam penelitian ini adalah bahwa adanya hubungan positif antara ketiga variabel penelitian yang telah disebutkan. Analisis regresi linier menegaskan bahwa responden memiliki ketergantungan linear positif yang tinggi dengan tanggung jawab lingkungan mereka.

Kuadrat koefisien korelasi antara pertama variabel $(\mathrm{r} 2 \mathrm{y} 1)$ sebesar 0,4529 dapat diinterpretasikan bahwa bila tidak dilakukan kontrol terhadap efikasi diri, maka $45 \%$ proporsi varians perilaku bertanggungjawab dapat dijelaskan oleh tingkat pengetahuan tentang lingkungan. Fakta ini terjadi karena efikasi diri dipengaruhi oleh hubungan individu dengan masyarakat dan pengalamannya sendiri (Mishra \& Shanwal, 2014)

Sedangkan dari bentuk hubungan antara pengetahuan tentang lingkungan (X2) dengan perilaku bertanggungjawab terhadap lingkungan (Y) ditunjukkan oleh persamaan garis regresi $\hat{\mathrm{Y}}=54,64+1,61 \mathrm{X} 2$. Persamaan garis regresi tersebut menunjukkan kebermaknaannya yang berarti pada taraf signifikansi 0,05. Persamaan garis tersebut dapat diinterpretasikan bahwa perubahan satu unit skor perilaku bertanggungjawab terhadap lingkungan akan diikuti oleh perubahan skor pengetahuan tentang lingkungan sebesar 1,61 unit pada arah yang sama dengan konstanta (interpect) sebesar 54,64.

Kedua, hasil pengujian hipotesis kedua dapat disimpulkan bahwa terdapat hubungan positif antara pengetahuan tentang lingkungan dengan perilaku bertanggungjawab terhadap lingkungan. Kesimpulan tersebut menunjukkan bahwa semakin tinggi pengetahuan lingkungan, akan semakin baik pula perilaku bertanggung jawab terhadap lingkungan.

Korelasi antara pengetahuan tentang lingkungan dengan perilaku bertanggungjawab terhadap lingkungan menunjukkan maknannya, baik melalui korelasi product moment maupun korelasi parsial. Hasil analisis ini memberikan petunjuk bahwa pengetahuan tentang lingkungan merupakan salah satu faktor utama yang berkonstribusi terhadap perilaku bertanggungjawab terhadap lingkungan. Dari hasil itu pula dapat diinterpretasikan bahwa peningkatan pengetahuan tentang lingkungan akan memberikan konstribusi yang berarti terhadap perilaku beertanggung jawab terhadap lingkungan.

\section{Keterbatasan Penelitian}

Penelitian ini telah dilakukan secara seksama oleh peneliti, namun demikian peneliti merasa yakin bahwa tidak semua gagasan dan 
pemikiran serta konsep-konsep yang seharusnya ada dapat dituangkan, sehingga peneliti mengakui bahwa penelitian ini mengandung berbagai keterbatasan-keterbatasan, terutama yang terkait dengan hal-hal berikut:

Pertama, variabel perilaku bertanggung jawab terhadap lingkungan ini tentunya dipengaruhi oleh banyak faktor, baik faktor internal maupun eksternal yang saling berinteraksi secara kompleks. Namun karena kemampuan peneliti yang terbatas, maka hanya dapat dikaji dua variabel yang ternyata berkontribusi terhadap perilaku bertanggungjawab terhadap lingkungan..

Kedua, kesulitan dalam melakukan kontrol terhadap variabel lain, sebagai akibat sifat, metode, jenis dan pendekatan penelitian yang dilakukan. Hal inilah yang memungkinkan munculnya keterbatasan terutama yang terkait dengan validitas internal dalam arti sejauh mana hasil penelitian ini dapat diterima sesuai dengan desain penelitian yang telah direncanakan.

\section{KESIMPULAN}

Pengetahuan lingkungan dan efikasi diri menunjukkan perannya terhadap perubahan positif responden dalam bertanggung jawab terhadap lingkungan.

\section{REFERENSI}

Abrahamse, W., \& Steg, L. (2009). How do Sociodemographic and Psychological Factors Relate to Households' Direct and Indirect Energy Use and Savings. Journal of Economic Psychology, 30, 711720.

Ary, D., Jacobs, L. C., Razavieh, A., \& Sorensen, C. K (2009). Introduction to Research in Education (Eighth). Belmont, USA: Wadsworth CENGAGE Learning.

Bandura, A. (2002). Environmental Sustainability by Sociocognitive Deceleration of Population Growth. in P. Schmuch \& W. Schultz (Eds.), The Psychology Of Sustainable Development. Kluwer: Dordrecht, the Netherlands.

Fischer, J. (2012). Human Behavior and Sustainability. Frontiers in Ecology and the Environment.

Gorontalo Pemprov, P. G. (2016). TPA Talumelito Raih Penghargaan Plakat Adipura Terbaik Nasional dari Kementerian Lingkungan Hidup. Retrieved from 31 Agustus 2016 website: https://www.gorontaloprov.go.id/informasi/berita/ kota-gorontalo

Huang, H. (2016). Media use, environmental beliefs, self-efficacy, and pro-environmental behavior. Journal of Business Research, 69(6), 2206-2212. https://doi.org/10.1016/j.jbusres.2015.12.031

Kadim, M. K., \& Pasisingi, N. (2017). Kajian kualitas perairan Teluk Gorontalo dengan menggunakan metode STORET. Depik Jurnal, 6(3), 235-241. https://doi.org/10.13170/depik.6.3.8442

Mishra, S., \& Shanwal, V. K. (2014). Role of Family Environment in Developing Self Efficacy of Adolescents. Integrated Journal of Social Sciences, I(Supplement 1), 28-30. https://doi.org/http://dx.doi.org/10.1111/fcp.12370

Osman, A. D., Jusoh, Amlus, \& Khotob, N. (2014). Exploring The Relationship Between Environmental Knowledge and Environmental Attitude Towards Pro-Environmental Behaviour: American-Eurasian Journal of Sustainable Agriculture, 8(8), 1-4. Retrieved from www.aensiweb.com/aejsa.html

Puspitaningtyas, Z. (2017). Pengaruh Efikasi Diri Dan Pengetahuan Manajemen Keuangan Bisnis Terhadap Intensi Berwirausaha. Jurnal Wira Ekonomi Mikroskil, 7(2), 141-150.

Riawan, B. (2016). Volume Sampah Gorontalo Mulai Mengkhawatirkan. Retrieved from http://rri.co.id/post/berita/708531/daerah/volume_s ampah_gorontalo_mulai_mengkhawatirkan.html

Sadik, F., \& Sadik, S. (2014). A Study on Environmental Knowledge and Attitudes of Teacher Candidates. Procedia - Social and Behavioral Sciences, 116, 2379-2385. https://doi.org/10.1016/j.sbspro.2014.01.577

Saribas, D., Teksoz, G., \& Ertepinar, H. (2014). The Relationship between Environmental Literacy and Self-efficacy Beliefs toward Environmental Education. Procedia - Social and Behavioral Sciences, 116, 3664-3668. https://doi.org/10.1016/j.sbspro.2014.01.820

Schutte, N. S., \& Bhullar, N. (2017). Approaching Environmental Sustainability: Perceptions of SelfEfficacy and Changeability. Journal of Psychology: Interdisciplinary and Applied, 151(3), 321-333. https://doi.org/10.1080/00223980.2017.1289144

Simanjuntak, P. M. (2016). Perilaku bertanggungjawab lingkungan siswa. IJEEM: Indonesian Journal of Environmental Education and Management, 1(2), 59-65. Retrieved from blob:http://journal.unj.ac.id/8672b4cf-84fe-40fe8f03-0453ac0d1d43

Slavoljub, J., Zivkovic, L., Sladjana, A., Dragica, G., \& Zorica, P. S. (2015). To the Environmental Responsibility among Students through Developing 
their Environmental Values. Procedia - Social and Behavioral Sciences, 171(January), 317-322. https://doi.org/10.1016/j.sbspro.2015.01.128

Sujarwanta, A. (2013). Pengaruh Metode Quantum Learning dan Pengetahuan Tentang Lingkungan terhadap Kepedulian Lingkungan (Studi Eksperimen pada Pembelajaran Pengetahuan Lingkungan di Universitas Muhammadiyah Metro Tahun Akademik 2011/2012. BIOEDUKASI (Jurnal Pendidikan Biologi), 4(1). https://doi.org/10.24127/bioedukasi.v4i1.211

Tabernero, C., \& Hernández, B. (2011). Self-efficacy and intrinsic motivation guiding environmental behavior. Environment and Behavior, 43(5), 658675. https://doi.org/10.1177/0013916510379759

UU RI No. RI 32 Tahun 2009. Perlindungan dan Pengelolaan Lingkungan Hidup. (2010). 